\title{
Retinoblastoma and mental retardation microdeletion syndrome: clinical characterization and molecular dissection using array CGH
}

\author{
R. Caselli $\cdot$ C. Speciale $\cdot$ C. Pescucci $\cdot$ V. Uliana $\cdot$ K. Sampieri $\cdot$ \\ M. Bruttini - I. Longo - S. De Francesco - T. Pramparo - O. Zuffardi · \\ R. Frezzotti - A. Acquaviva $\cdot$ T. Hadjistilianou $\cdot$ A. Renieri $\cdot$ F. Mari
}

Received: 28 February 2007 / Accepted: 31 March 2007/Published online: 15 May 2007

(C) The Japan Society of Human Genetics and Springer 2007

\begin{abstract}
We describe three patients with retinoblastoma, dysmorphic features and developmental delay. Patients 1 and 2 have high and broad forehead, deeply grooved philtrum, thick anteverted lobes and thick helix. Patient 1 also has dolicocephaly, sacral pit/dimple and toe crowding; patient 2 shows intrauterine growth retardation and short fifth toe. Both patients have partial agenesis of corpus callosum. Patient 3 has growth retardation, microcephaly, thick lower lip and micrognathia. Using array-comparative genomic hybridization (CGH), we identified a 13q14 de novo deletion in patients 1 and 2, while patient 3 had a 7q11.21 maternally inherited deletion, probably not related to the disease. Our results confirm that a distinct facial phenotype is related to a $13 \mathrm{q} 14$ deletion. Patients with retinoblastoma and malformations without a peculiar facial
\end{abstract}

R. Caselli · C. Speciale - C. Pescucci · V. Uliana ·

K. Sampieri - M. Bruttini - I. Longo · A. Renieri (凹) .

F. Mari

Medical Genetics, Department of Molecular Biology,

University of Siena, Policlinico Le Scotte,

V.le Bracci 2, 53100 Siena, Italy

e-mail: renieri@unisi.it

T. Pramparo $\cdot$ O. Zuffardi

Biologia Generale e Genetica Medica, University of Pavia, Pavia, Italy

R. Frezzotti

Department of Ophthalmology, University of Siena,

Siena, Italy

\section{A. Acquaviva}

Department of Pediatrics, University of Siena,

Siena, Italy

S. De Francesco · T. Hadjistilianou

Department of Ophthalmology, Retinoblastoma Referral Center,

Siena, Italy phenotype may have a different deletion syndrome or a casual association of mental retardation and retinoblastoma. Using array-CGH, we defined a critical region for mental retardation and dysmorphic features. We compared this deletion with a smaller one in a patient with retinoblastoma (case 4) and identified two distinct critical regions, containing 30 genes. Four genes appear to be good functional candidates for the neurological phenotype: NUFIP1 (nuclear fragile $\mathrm{X}$ mental retardation protein 1), HTR2A (serotonin receptor 2A), PCDH8 (prothocaderin 8) and $\mathrm{PCDH} 17$ (prothocaderin 17).

Keywords 13q14 deletion syndrome - Developmental delay $\cdot$ Mental retardation - Retinoblastoma - Array-CGH

\section{Introduction}

Retinoblastoma is the most common intraocular tumor of early childhood, with an incidence of 1/15,000-28,000 live births. Tumor development is caused by inactivation of both alleles of the $R B 1$ gene located in 13q14.2. In 68\% of cases $R B 1$ is inactivated by point mutations, in $5 \% R B 1$ complete gene deletions have been found, while gross-sized molecular deletions have been found in 10\% of cases (Albrecht et al. 2005; Dahiya et al. 2000; Kloss et al. 1991; Lohmann and Gallie 2004; Sampieri et al. 2006). When the deletion involves part of the $R B 1$ surrounding genome it causes a contiguous gene deletion syndrome characterized by retinoblastoma, developmental abnormalities and peculiar facial dysmorphisms. The first author to suggest a specific facial phenotype associated with 13q14 deletion was Motegi in 1983 (Motegi et al. 1983). He described two patients with retinoblastoma and common facial features including prominent eyebrows, broad nasal bridge, bulbous nasal tip, 
large mouth, thin upper lip and long philtrum (Motegi, et al. 1983). A few years later, he described an additional patient, and was able to improve the clinical definition of the syndrome (Motegi et al. 1987). In 1999, Baud et al. (1999) defined the dysmorphic features of 13q14 deletion syndrome. He described a cohort of 22 patients with the following common dysmorphic abnormalities: high and broad forehead, thick and everted ear lobes, short nose, prominent philtrum and thick everted lower lip (Baud et al. 1999). In 2001, Bojinova et al. (2001) extended the facial phenotype associated with the 13q14 deletion syndrome with the description of additional 13 patients characterized by cranial anomalies, frontal bossing, deeply grooved and long philtrum, depressed and broad nasal bridge, bulbous tip of the nose, thin upper lip, broad cheeks, and large ears and lobules. Afterward, a patient with a X:13 translocation and phenotypic features peculiar to the 13q14 deletion syndrome was described (Dries et al. 2003). Finally, in 2004, a patient with retinoblastoma, pinealoma and mild multiple congenital anomalies/mental retardation syndrome (MCA/MR) and a germline 13q14 deletion were reported (Skrypnyk and Bartsch 2004).

All these reported cases were studied by means of cytogenetic analysis. We investigated using array-based comparative genomic hybridization (array-CGH) three patients with retinoblastoma and MCA/MR. Using the same method, we analyzed an additional patient with isolated retinoblastoma and a previously identified RB1 deletion (Sampieri et al. 2006) to attempt to define a minimal critical region for MCA/MR. Patients were selected among the cohort of retinoblastoma cases collected in the biobank of the Medical Genetics Unit of the University of Siena (http://www.biobank.unisi.it). Here we report an accurate clinical and molecular characterization of these patients.

\section{Materials and methods}

Array-CGH analysis

Array-CGH analysis was performed using commercially available oligonucleotide microarrays containing approximately 43,000 60-mer probes (Human Genome CGH Microarray 44B Kit. Agilent Technologies, Santa Clara, California), as previously reported (Pescucci et al. 2006). The average resolution is about $75-100 \mathrm{~kb}$.

\section{Real-time quantitative PCR}

Real-time quantitative polymerase chain reaction (PCR) was performed to confirm array-CGH data. We used
TaqMan Gene Expression Assays by design (Applied Biosystems, http://www.products.appliedbiosystems.com), which provides a pre-designed primers-probe set for realtime PCR experiments. In order to validate the presence of the 13q deletion in cases 1, 2 and 4, we used the TaqMan probe and primers in exon 17 of RB1, as previously described (Sampieri et al. 2006). For validating the presence of the $7 \mathrm{q}$ deletion in case 3 , we designed the probe in the BC066990 sequence related to the 7q11.21 locus. Forward primer: 5'-GTG CTG TAG TGC AGA ATG TAA CAA A-3'; reverse primer: 5'-CAG AAA GCC AAG AAT AAC-3'; TaqMan probe: $5^{\prime}$-AGG GTG AAC AAA ACC AGT TGA GTT-3'. PCR was carried out using an ABI prism 7000 (Applied Biosystems) in a 96-well optical plate with a final reaction volume of $50 \mu \mathrm{l}$. A total of $100 \mathrm{ng}(10 \mu \mathrm{l})$ was dispensed in each of the four sample wells for quadruplicate reactions. Thermal cycling conditions included a prerun of $2 \mathrm{~min}$ at $50^{\circ} \mathrm{C}$ and $10 \mathrm{~min}$ at $95^{\circ} \mathrm{C}$. Cycle conditions were 40 cycles at $95^{\circ} \mathrm{C}$ for $15 \mathrm{~s}$ and $60^{\circ} \mathrm{C}$ for $1 \mathrm{~min}$, according to the TaqMan Universal PCR Protocol (ABI). The TaqMan Universal PCR Master Mix and Microamp reaction tubes were supplied by Applied Biosystem. The starting copy number of the unknown samples was determined using the comparative Ct method, as previously described (Livak 1997).

\section{RB1 mutation analysis}

Genomic DNA was amplified by PCR. Primers and PCR conditions for single exons and promoter analysis have been described previously (Hogg et al. 1992; Houdayer et al. 2004; Scheffer et al. 2000). PCR products were mixed with an equal volume of formamide, denatured by heating at $95^{\circ} \mathrm{C}$ for $5 \mathrm{~min}$, followed by immediate chilling on ice. Single-strand conformational polymorphism (SSCP) was performed on a Genephor apparatus (Pharmacia Amersham, Little Braunschweig, Germany) using a GeneGel Excel 12.5/24 Kit (Pharmacia Amersham).

\section{Results}

Clinical description

Case 1

Patient number 1, a 1-year and 2-month-old female, is the first and only child of healthy unrelated parents (Fig. 1a). At birth, the mother and father were 28 and 33 years old, respectively. Their family history was unremarkable. No teratogen exposure during pregnancy had been reported. The child was born on term by means of caesarean delivery. 
(A)
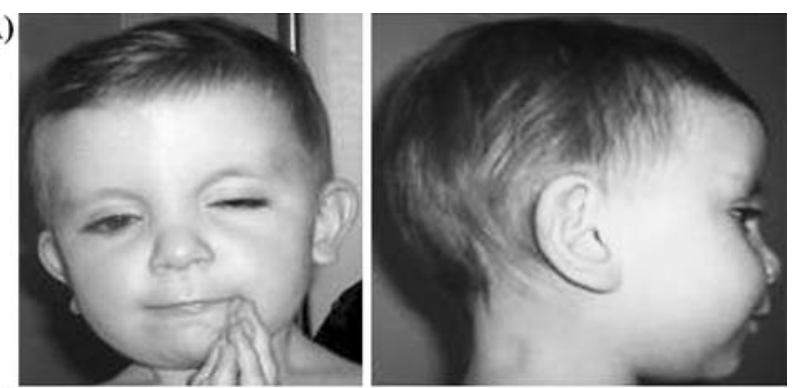

(B)

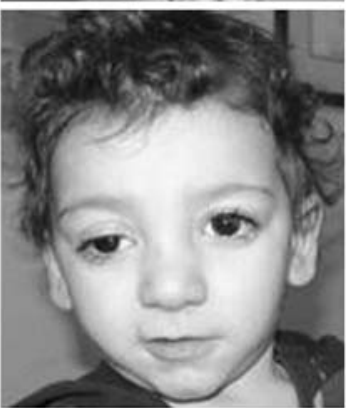

(C)
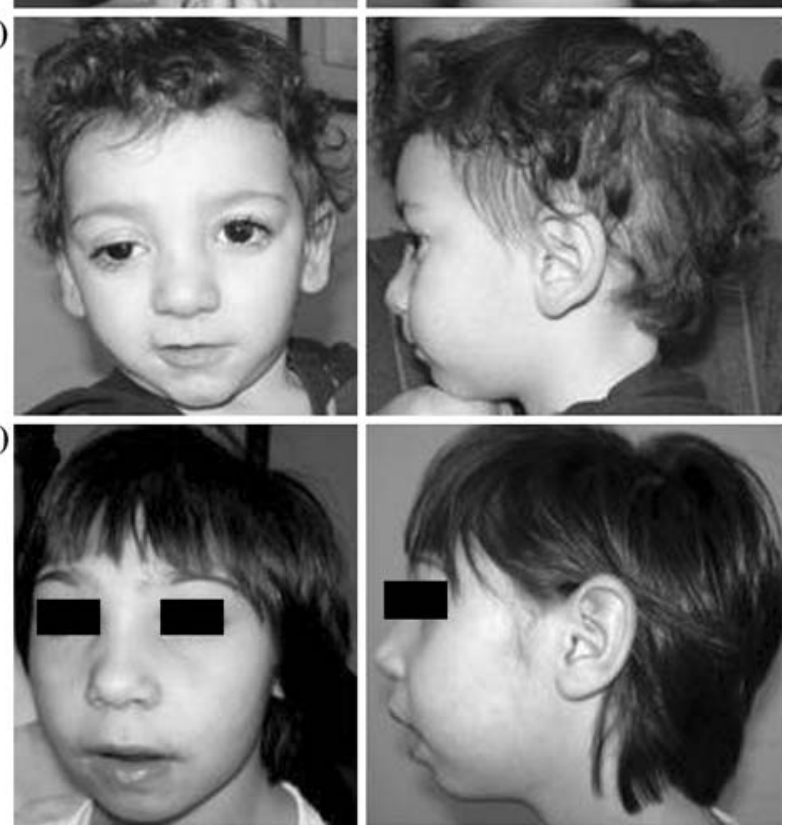

Fig. 1 Face and profile views of the patients. a Case 1: patient no. 1 at the age of 1 year 2 months. Frontal view showing high and broad forehead, deeply grooved philtrum. Side view showing dolicocephaly and thick anteverted lobes and helix. b Case 2: patient no. 2 at the age of 2 years 7 months. Frontal view showing hypotelorism, long palpebral fissures, epichantic folds, slight unilateral ptosis and thick and everted lower lip. Thick anteverted lobes and helix are showed on the side view. c Case 3: patient no. 3 at the age of 7 years 6 months. Frontal view showing sparse eyebrows in the medial third broad nasal bridge, bulbous tip of the nose, long philtrum, thick and everted lower lip. Side view showing large ears and micrognathia

Birth weight was $3,130 \mathrm{~g}$ (50th percentile), length was $51 \mathrm{~cm}$ (50th percentile) and head circumference was $36 \mathrm{~cm}$ ( $>90$ th percentile). Bilateral retinoblastoma was diagnosed at 5 months of age. At that time, MRI revealed corpus callosum hypoplasia. ABR and ankle ultrasonography were normal. At our first examination (6 months), psychomotor development was slightly delayed. Her weight was $7.850 \mathrm{~g}$ (75th percentile), length $68 \mathrm{~cm}$ (90th percentile) and head circumference $46 \mathrm{~cm}$ (97th percentile) with dolicocephaly. The patient presented scalp anomalies including widely open fontanelles and an alopecic area on the right temporoparietal region. High and broad forehead, deeply grooved philtrum, and thick anteverted lobes and thick helix were noted. In addition, she showed sacral dimple and
(A)
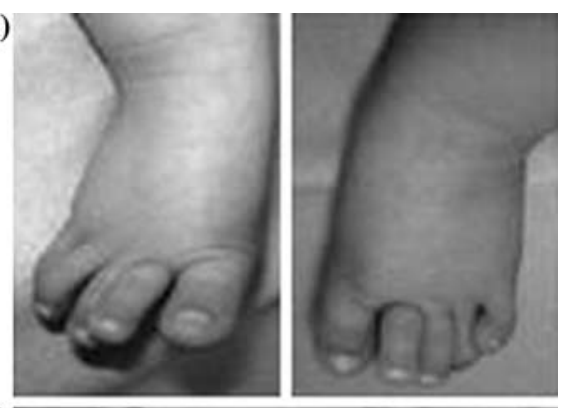

(B)

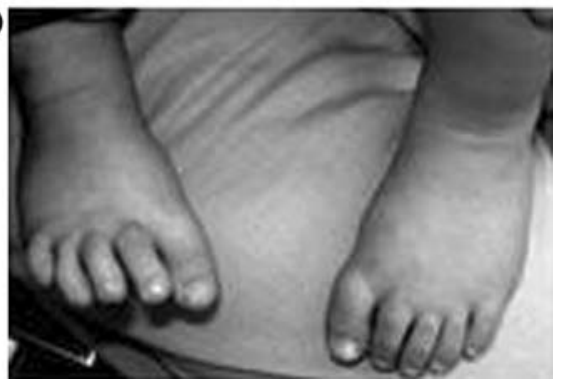

Fig. 2 Toe anomalies in cases 1(a) and 2(b). a View of the right feet showing toe crowding. Note clinodactyly of the 5 th toe on the left foot. b Note short 5th toe with hypoplastic toe nail

clinodactyly of the 5th toe on the left and toe crowding on the right (Fig. 2a). At the age of 11 months, she presented with a relapse in the right eye treated by chemotherapy. Two months later, the right eye was enucleated. In the following months, a relapse in the left eye occurred, which was treated successfully by means of radiotherapy. At our second clinical examination (14 months), her weight was $9 \mathrm{~kg}$ (10-25th percentile), length 76-77 cm (50th percentile) and head circumference $49 \mathrm{~cm}(>97$ th percentile). Psychomotor delay persisted. Ultrasound cardiac examination was normal (Table 1).

\section{Case 2}

Patient number 2, a 2-year and 7-month-old boy, is the third-born of healthy and non-consanguineous parents (Fig. 1b). Intrauterine growth retardation was noted at the 36th week of gestation. He was born on term. At birth, his weight was $2,300 \mathrm{~g}$ ( $<3 \mathrm{rd}$ percentile), length was $47 \mathrm{~cm}$ (10-25th percentile) and OFC was $32 \mathrm{~cm}$ (3rd-10th percentile). He demonstrated a deficit of thermoregulation. On the 11th day, he presented with enterococcus sepsis. During the first months of life, the parents noted iris bilateral heterochromia. Right eye retinoblastoma was diagnosed at 10 months of age. At 1 year of age, a MRI was performed and hypoplasia of the corpus callosum was noted. By 1 year and 5 months of age, he suffered a relapse, which was treated by enucleation. At our first examination ( 2 years of age) his height was $78 \mathrm{~cm}(<3 \mathrm{rd}$ percentile), weight $8,250 \mathrm{~kg}(<<3 \mathrm{rd}$ percentile $)$ and OFC $44 \mathrm{~cm}(<<3 \mathrm{rd}$ 
Table 1 Clinical findings in patients with retinoblastoma, dysmorphic features and developmental delay

\begin{tabular}{llll}
\hline Dysmorphic features & Age & \\
\cline { 2 - 4 } & Case 1 $(\neq 133)$ & Case 2 $(\neq 129)$ & Case 3 ( $\neq 76)$ \\
& 1 year 2 month & 2 year 7 month & 7 year 6 month \\
\hline Thick anteverted lobes & + & + & - \\
Thick helix & + & + & - \\
High and broad forehead & + & + & - \\
Deeply grooved philtrum & + & $+/-$ & - \\
Short nose & - & + & + \\
Thick everted lower lip & - & + & - \\
Cardiac anomaly & - & - & - \\
Brain anomaly & Partial corpus & Corpus callosum hypoplasia & - \\
Skeletal abnormality & callosum agenesis & & - \\
Growth retardation & Toe crowding & Short V toe & $+/-$ \\
Other & - & $+(<3$ cnt $)$ & Microcephaly \\
& Dolicocephaly & Iris heterochromya & $(<<3$ cnt $)$ \\
& Alopecia & & Cutis mormorata \\
& Sacral pit & & epicanthic folds \\
\hline
\end{tabular}

percentile). He showed hypotonia and particular facial features including high and broad forehead, deeply grooved philtrum, thick and everted lower lip, thick and everted auricular lobes, and thick helix. Moreover, he had short 5th toe with hypoplastic toenail (Fig. 2b). A second clinical examination 7 months later confirmed growth delay: $80 \mathrm{~cm}$ in height ( $<5$ th percentile), weight $9.0 \mathrm{~kg}(<<3 \mathrm{rd}$ percentile) and OFC $45 \mathrm{~cm}(<<3 \mathrm{rd}$ percentile). The previously noted facial features were still present. There were no abnormalities of other organs and systems. He reached selfgoverning deambulation at 2 years and 6 months. Presently, he is able to say only few words and he has no sphincter control. An echocardiogram showed minimum aortic reflux, probably due to the infantile infection. X-rays of hands and toes indicated no abnormalities (Table 1).

\section{Case 3}

Patient number 3, a 7-year and 11-month-old female, is the first-born of healthy, non-consanguineous parents (Fig. 3c) at birth, the mother was 35 years and the father 47 years old. After bearing this child, the mother later had a spontaneous abortion. However, this patient does have a 19year-old maternal half-sister suspected to have Gilles De La Tourette syndrome; the mother had a spontaneous abortion after her birth. During gestation, ultrasound study revealed microcephaly. This patient was born on term and her weight was $2,780 \mathrm{~g}$ (10-25th percentile); data on length and OFC are not available. Development has been slightly delayed: she reached self-governing deambulation at 20 months of age and was able to say her first words when she was 2 years old. At 2.5 years of age, her mother noted right leucoria. Unilateral retinoblastoma was diagnosed and treated with eye enucleation. At our first examination ( 5 years and 7 months of age), her weight was $14 \mathrm{~kg}$ (<5th percentile), height $109.5 \mathrm{~cm}$ (25-50th percentile) and OFC $41 \mathrm{~cm} \quad(<<3 \mathrm{rd}$ percentile). Physical examination showed sparse eyebrows in the medial third, epichantic folds, broad nasal bridge, bulbous nasal tip, long philtrum, thick and everted lower lip, large ears, micrognathia and cutis marmorata. She also showed a moderate mental retardation (Table 1). A second clinical examination at 7 years and 11 months of age confirmed short stature $(115 \mathrm{~cm},<5$ th percentile), the same previously described facial features and microcephaly (OFC $42 \mathrm{~cm}$, $<<3$ rd percentile).

\section{Case 4}

Patient number 4, a 5-year and 4-month-old female, is the second child of unrelated parents. At birth, the mother was 20 years and the father 26 years old. Paternal history was unremarkable and the first child of the couple is healthy. The mother and a younger brother, however, have been affected by retinoblastoma. The mother presented with retinoblastoma in the left eye at 11 months of age and enucleation was immediately performed. In the younger brother, the diagnosis was made at 40 days of life. In the second child, patient number 4 , the gestation of the proband was unremarkable and no teratogen exposure was reported. Multifocal retinoblastoma in the left eye was diagnosed at 2 years and 7 months. After four cycles of chemotherapy, the tumors showed good regression but three relapses occurred and enucleation was performed. 
(A) 13

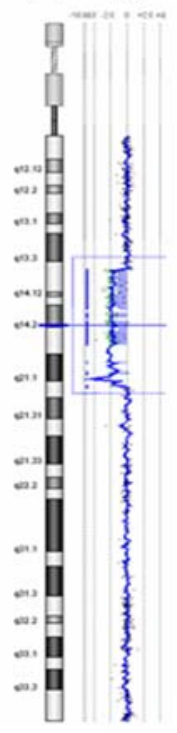

case 1

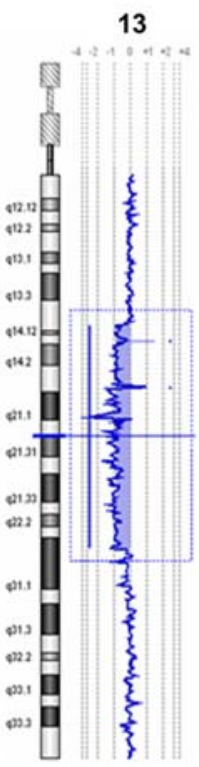

case 2

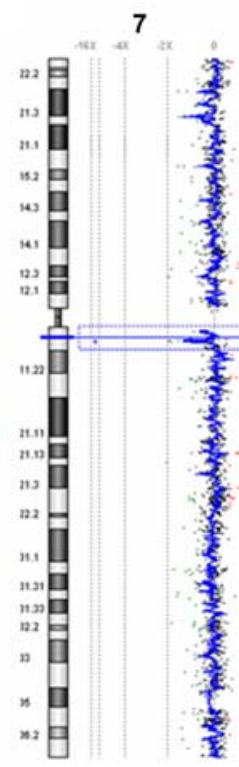

case 3

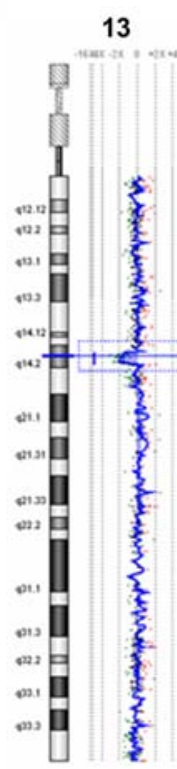

case 4
(B)

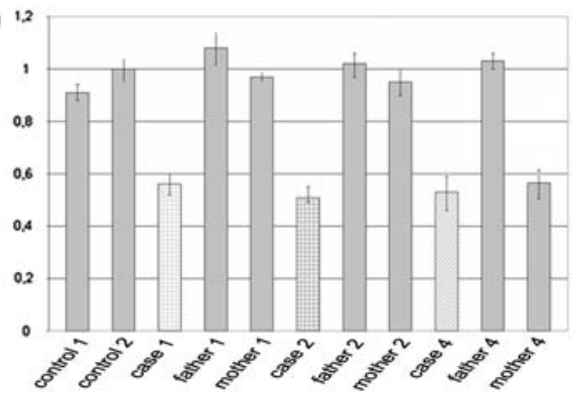

(C)

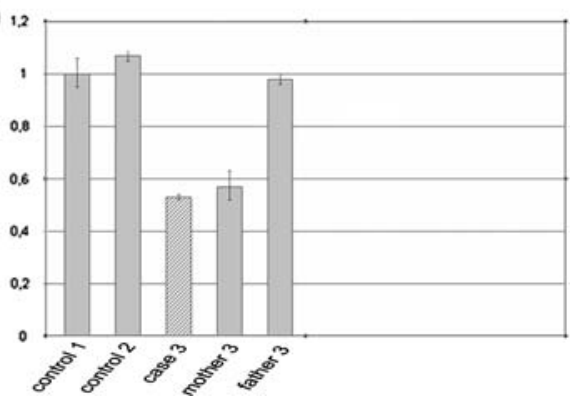

Fig. 3 Patients' molecular data. a Array CGH ratio profiles. On the left, chromosome ideogram for each case. On the right, the $\log 2$ ratio of the chromosome probes plotted as a function of chromosomal position. Oligos with a value of zero represent equal fluorescence intensity ratio between sample and reference. Each dot represents a single probe (oligo) spotted on the array. Copy number loss shifts the ratio to the left (value of about $-2 \mathrm{X}$ ). $\mathbf{b}$ and $\mathbf{c}$ Real-time quantitative PCR validation experiment. b RB1 ddCT ratios and standard deviations of two different controls and of patients 1,2 and 4 and their parents. Patients 1,2 and 4 and the mother of 4 show a ddCT ratio of about 0.5 , indicating the presence of a single copy of RB1 (deletion). The parents of patients 1 and 2 and the father of patient 4 , as the controls, show ddCT ratios of about 1.0, which indicates a double copy of the gene. c BC066990 sequence ratios and standard deviations of two different controls and of patient 3 and her parents. The patient and the mother show ddCT ratio of about 0.5 , indicating the presence of a single copy of BC066990 sequence (deletion); while the father, like the controls, shows ddCT ratios of about 1.0 indicating a double copy of the sequence
During ophthalmological follow-up, no foci were noted in the right eye. On clinical examination, neither mental retardation nor dysmorphisms have been noted. Isolated unilateral retinoblastoma was the unique clinical sign.

\section{Molecular characterization}

Point mutation analysis of promoter and coding sequences of the $R B 1$ gene in the four cases did not reveal any alterations.

Oligonucleotide array-CGH analysis with an averaged spatial resolution of approximately $75 \mathrm{~kb}$ was performed on DNA from the four patients. The analysis of ratio profiles in cases 1, 2 and 4 revealed a different sized interstitial deletion in the long arm of chromosome 13. Based on the array findings, the deleted region observed in case 1 was found to extend approximately $19 \mathrm{Mb}$ [46,XXdel(13)(q13.3q21.2)]. The proximal breakpoint is mapped in 13q13.3 (last oligonucleotide present located in $40.34 \mathrm{Mb}$, first deleted in $40.40 \mathrm{Mb}$ position), while the distal breakpoint is located between 59.29 and $59.36 \mathrm{Mb}$ in 13q21.2 (last oligonucleotide deleted and first present, respectively) (Fig. 3a).
The deleted region seen in case 2 is approximately $36 \mathrm{Mb}$ in size [46,Xydel(13)(q14.11q31.1)]. In this case, the proximal breakpoint is mapped in 13q14.11 (last oligonucleotide present located in $43 \mathrm{Mb}$, first deleted in $43.24 \mathrm{Mb}$ position), while the distal breakpoint is located between 79.27 and $79.80 \mathrm{Mb}$ in $13 \mathrm{q} 31.1$ (last oligonucleotide deleted and first present, respectively) (Fig. 3a). In contrast, the array$\mathrm{CGH}$ analysis of case 3 revealed a $200-\mathrm{kb}$ proximal deletion on chromosome 7q [46,XX del(7)(q11.21)](Fig. 3a).

The array-CGH analysis of case 4 allowed us to identify an interstitial deletion of approximately $1.7 \mathrm{Mb}$ [46,XX del(13)(q14.2)]. In this case, both breakpoints are located in 13q14.2 (last oligonucleotide present located in $47.35 \mathrm{Mb}$, first deleted in $47.44 \mathrm{Mb}$ position while last oligonucleotide deleted in $49.10 \mathrm{Mb}$ position and first oligonucleotide present in $49.17 \mathrm{Mb}$ position). In order to confirm array findings, real-time Quantitative PCR experiments were performed in the patients and their parents. In all cases, the deletion was confirmed. Identified deletions of the long arm of chromosome 13 were de novo in patients 1 and 2 and inherited in 4. The 7q microdeletion in patient 3 was inherited from the unaffected mother (Fig. 3b, c). 


\section{Discussion}

Two distinct syndromes are associated with deletions involving different regions of the long arm of chromosome 13. One of these syndromes is caused by a more distal deletion that involves band q32 and is phenotypically characterized by the presence of severe mental retardation, major malformations and digital anomalies (Brown et al. 1993, 1995). The other one is due to a proximal deletion that involves band q14 and is associated with retinoblastoma and mental retardation. Baud et al. defined the peculiar facial traits of this syndrome that is characterized by anteverted ear lobes, high and broad forehead, and a prominent philtrum (Baud et al. 1999; Motegi et al. 1987, 1983)

The facial features of patients 1 and 2 suggest the $13 q 14$ deletion syndrome described by Baud et al. 1999 (Table 1). In particular, both patients have high and broad foreheads, deeply grooved philtrum, thick and anteverted lobes and thick helices. These characteristics are absent in patient 3 . As expected on the basis of clinical examination, array $\mathrm{CGH}$ analysis confirmed a 13q14 deletion syndrome in patients 1 and 2 but not in 3 . Our findings confirm that $13 q 14$ deletion syndrome is characterized by specific facial features and that this diagnosis may be strongly suspected on a clinical ground even before the genetic test.

A more complex situation is present in case 3 . The presence of the small $7 \mathrm{q}$ deletion in the unaffected mother suggests that this deletion is not responsible for the clinical phenotype in this patient. In addition, a known copy-number polymorphism (CNP) is located at a distance of $80 \mathrm{~kb}$ from our deletion (http://www.projects.tcag.ca/bioxrt/), and the deletion is included in a region of highly homologous duplicated sequences (Sharp et al. 2005). However, three different imprinted regions located on the long arm of chromosome 7 have already been described (http:// www.geneimprint.com/site/genes-by-species.Homo+sapiens.imprinted-All). Consequently, additional analyses are necessary to investigate whether the deleted region is imprinted and to definitively rule out the involvement of this small deletion in the clinical phenotype of the patient.

Deletions identified in cases 1 and 2 partially overlap and allowed us to define a minimal critical region for mental retardation and dysmorphic features of about $16 \mathrm{Mb}$ that includes 39 known genes.

Comparison of this critical region with the $13 \mathrm{q} 14.2$ deletion present in case 4 with isolated retinoblastoma allowed us to exclude a central region containing 9 known genes. Consequently, we identified two distinct critical regions, a centromeric sub-region of about $4 \mathrm{Mb}$ and a telomeric one of about $10 \mathrm{Mb}$. Gene content analysis of the centromeric sub-region showed the presence of 14 known genes (Fig. 4, Table 2). Among them, NUFIPl is of particular interest due to its putative role in central nervous system (CNS) development and to its preferential brain expression. The NUFIP1 gene encodes for a nucleo-cytoplasmatic RNA binding protein: FMRP interacting protein 1. NUFIP1 interacts with FMRP, the protein disrupted in Fragile X Mental Retardation (Bardoni et al. 2003). In particular, NUFIP1 could be involved in the regulation of local protein synthesis near active synapses in association with FMRP (Bardoni et al. 2003). Due to its role in synaptic plasticity, NUFIP1 could be a good candidate gene for mental retardation in our patients. The HTR2A gene is located within the centromeric deleted sub-region. This gene codifies for a receptor of serotonin. Disturbances in
Fig. 4 Gene content of the deleted region (UCSC Genome Browser; http://

www.genome.ucsc.edu). a Comparison between deletions observed in cases 1 and 2 and minimal critical region. b Gene content of the two critical sub-regions. Orange rectangles delimit deleted region identified in case 4 . Circled genes are discussed in the text

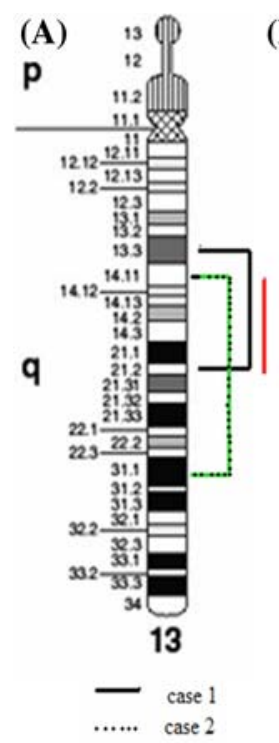

(B)

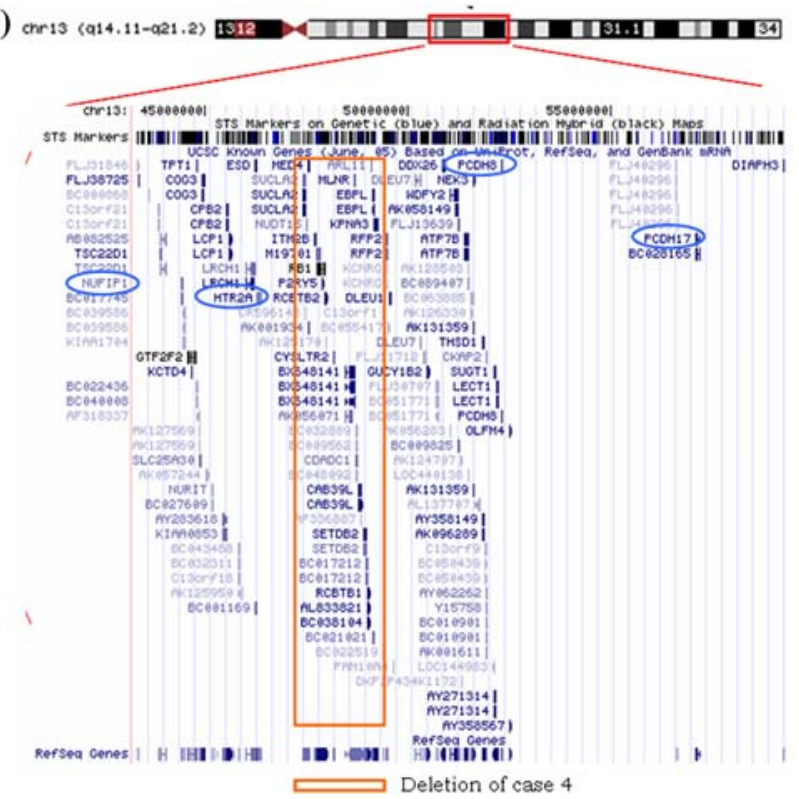


Table 2 Centromeric critical region

\begin{tabular}{|c|c|c|}
\hline Gene symbol & Gene name & Note \\
\hline TSC22D1 & TSC22 domain family 1 & \\
\hline NUFIP1 & Nuclear fragile $\mathrm{X}$ mental retardation protein 1 & \\
\hline GTF2F2 & General transcription factor IIF, polypeptide 2 & \\
\hline KCTD4 & $\begin{array}{l}\text { Potassium channel tetramerisation domain } \\
\text { containing protein } 4\end{array}$ & \\
\hline TPT1 & Histamine-releasing factor & \\
\hline COG3 & Component of Golgi transport complex 3 & \\
\hline NURIT & Testis-specific leucine zipper protein nurit & \\
\hline SLC25A30 & Solute carrier family 25 , member 30 & \\
\hline$\underline{\mathrm{ZC} 3 \mathrm{H} 13}$ & Zinc finger CCCH-type containing 13 & \\
\hline CPB2 & Plasma carboxypeptidase B2 isoform a & \\
\hline$\underline{\mathrm{LCP} 1}$ & Lymphocyte cytosolic protein 1 & \\
\hline$\underline{\mathrm{LRCH} 1}$ & Leucine-rich repeats and calponin homology & \\
\hline ESD & Esterase D & \\
\hline$\underline{\mathrm{HTR} 2 \mathrm{~A}}$ & Serotonin receptor $2 \mathrm{~A}$ & $\begin{array}{l}\text { Polymorphisms have been studied in } \\
\text { association with ADHD, Alzheimer } \\
\text { disease and behavioral disorders }\end{array}$ \\
\hline
\end{tabular}

Table 3 Telomeric critical region

\begin{tabular}{|c|c|c|}
\hline Gene symbol & Gene name & Note \\
\hline$\underline{\mathrm{RFP} 2}$ & Ret finger protein 2 isoform 2 & $\begin{array}{l}\text { Involved in B-cell chronic lymphocytic } \\
\text { leukemia in } 13 q 14 \text { deletion }\end{array}$ \\
\hline$\underline{\mathrm{KCNRG}}$ & Potassium channel regulator & $\begin{array}{l}\text { Candidate for B-cell chronic lymphocytic } \\
\text { leukemia and prostate cancer } \\
\text { tumor suppressor }\end{array}$ \\
\hline$\underline{\text { DLEU1 }}$ & Deleted in lymphocytic leukemia, 1 & $\begin{array}{l}\text { Leukemia associated protein } 1 \text { may act } \\
\text { as tumor suppressor }\end{array}$ \\
\hline$\underline{\text { DLEU7 }}$ & Deleted in lymphocytic leukemia, 7 & \\
\hline$\underline{\mathrm{DDX} 26}$ & DEAD/H box polypeptide 26 & \\
\hline$\underline{\text { WDFY2 }}$ & $\begin{array}{l}\text { WD repeat and FYVE domain-containing } \\
\text { protein } 2\end{array}$ & \\
\hline$\underline{\text { GUCY1B2 }}$ & Guanylate cyclase 1 , soluble, beta 2 & \\
\hline$\underline{\text { ATP7B }}$ & ATPase beta polypeptide & $\begin{array}{l}\text { Homozygous mutations have been } \\
\text { associated with Wilson disease }\end{array}$ \\
\hline NEK3 & Serine/threonine-protein kinase Nek 3 & \\
\hline$\underline{\text { THSD1 }}$ & Thrombospondin type I domain-containing 1 & \\
\hline$\underline{\text { TMAP }}$ & $\begin{array}{l}\text { Tumor-associated microtubule-associated } \\
\text { protein }\end{array}$ & \\
\hline$\underline{\text { SUGT1 }}$ & Suppressor of G2 allele of SKP1 & \\
\hline$\underline{\text { LECT1 }}$ & Leukocyte cell-derived chemotaxin 1 & \\
\hline$\underline{\mathrm{PCDH} 8}$ & Protocadherin 8 & \\
\hline$\underline{\mathrm{PCDH} 17}$ & Protocadherin 17 & \\
\hline DIAPH3 & Diaphonous protein homolog 3 & \\
\hline
\end{tabular}

the serotonergic neurotransmission system may be responsible for behavioral disorders (Bruce et al. 2005). In particular, a polymorphism in the HTR2A gene was associated with the remission of attention deficit/hyperactivity disorder (ADHD) (Li et al. 2006). Disruption of serotonin receptor activity may contribute to $\mathrm{CNS}$ disorders that have been associated with impaired development.
Gene content analysis of the deleted telomeric sub-region showed the presence of 16 known genes (Fig. 4, Table 3). Among them, $\mathrm{PCDH} 8$ and $\mathrm{PCDH} 17$ may be good candidates for the generation of the neurological phenotype in our patients. These genes belong to the protocadherin gene family and codify for integral membrane proteins, which are thought to function in signaling pathways and in cell 
adhesion in a CNS-specific manner. The role of Pcdh8 in the nervous system was investigated in rat hippocampus (Yamagata et al. 1999). Antibodies against Pcdh8 attenuate basal synaptic transmission and completely inhibit longterm potentiation in hippocampal slices (Yamagata et al. 1999). The expression and function of the $P C D H 17$ gene is not well known.

To date, all 48 cases with a $13 \mathrm{q} 14$ microdeletion reported in the literature have been characterized at the cytogenetic level. This is the first report of characterization at the molecular level, using array-CGH, of patients with retinoblastoma and mental retardation, and a critical region for mental retardation is defined. Further experiments are necessary to narrow this critical region and to dissect the syndrome, thus identifying the gene(s) responsible for the neurological phenotype in these patients.

Acknowledgments This work was supported by grants from Pierfranco e Luisa Mariani Foundation and from Telethon Foundation (GTF05005) to A.R. and by a Grant on Retinoblastoma from Istituto Toscano Tumor (ITT) to A.R.

\section{References}

Albrecht P, Ansperger-Rescher B, Schuler A, Zeschnigk M, Gallie B, Lohmann DR (2005) Spectrum of gross deletions and insertions in the RB1 gene in patients with retinoblastoma and association with phenotypic expression. Hum Mutat 26(5):437-445

Bardoni B, Willemsen R, Weiler IJ, Schenck A, Severijnen LA, Hindelang C, Lalli E, Mandel JL (2003) NUFIP1 (nuclear FMRP interacting protein 1 is a nucleocytoplasmic shuttling protein associated with active synaptoneurosomes. Exp Cell Res 289(1):95-107

Baud O, Cormier-Daire V, Lyonnet S, Desjardins L, Turleau C, Doz F (1999) Dysmorphic phenotype and neurological impairment in 22 retinoblastoma patients with constitutional cytogenetic $13 \mathrm{q}$ deletion. Clin Genet 55(6):478-82

Bojinova RI, Schorderet DF, Addor MC, Gaide AC, Thonney F, Pescia G, Nenadov-Beck M, Balmer A, Munier FL (2001) Further delineation of the facial 13q14 deletion syndrome in 13 retinoblastoma patients. Ophthalmic Genet 22(1):11-18

Brown S, Gersen S, Anyane-Yeboa K, Warburton D (1993) Preliminary definition of a "critical region" of chromosome 13 in q32: report of 14 cases with 13q deletions and review of the literature. Am J Med Genet 45(1):52-59

Brown S, Russo J, Chitayat D, Warburton D (1995) The 13qsyndrome: the molecular definition of a critical deletion region in band 13q32. Am J Hum Genet 57(4):859-866

Bruce KR, Steiger H, Joober R, Ng Ying Kin NM, Israel M, Young SN (2005) Association of the promoter polymorphism -1438G/A of the 5-HT2A receptor gene with behavioral impulsiveness and serotonin function in women with bulimia nervosa. Am J Med Genet B Neuropsychiatr Genet 137(1):40-44

Dahiya A, Gavin MR, Luo RX, Dean DC (2000) Role of the LXCXE binding site in Rb function. Mol Cell Biol 20(18):6799-6805

Dries D, Baca K, Truss L, Dobin S (2003) Interstitial deletion of 13q and a $13 ; \mathrm{X}$ chromosome translocation results in partial trisomy
13 and bilateral retinoblastoma. Ophthalmic Genet 24(3):175180

Hogg A, Onadim Z, Baird PN, Cowell JK (1992) Detection of heterozygous mutations in the RB1 gene in retinoblastoma patients using single-strand conformation polymorphism analysis and polymerase chain reaction sequencing. Oncogene 7(7):1445-1451

Houdayer C, Gauthier-Villars M, Lauge A, Pages-Berhouet S, Dehainault C, Caux-Moncoutier V, Karczynski P, Tosi M, Doz F, Desjardins L, Couturier J, Stoppa-Lyonnet D (2004) Comprehensive screening for constitutional RB1 mutations by DHPLC and QMPSF. Hum Mutat 23(2):193-202

Kloss K, Wahrisch P, Greger V, Messmer E, Fritze H, Hopping W, Passarge E, Horsthemke B (1991) Characterization of deletions at the retinoblastoma locus in patients with bilateral retinoblastoma. Am J Med Genet 39(2):196-200

Li J, Kang C, Wang Y, Zhou R, Wang B, Guan L, Yang L, Faraone SV (2006) Contribution of 5-HT2A receptor gene -1438A > G polymorphism to outcome of attention-deficit/hyperactivity disorder in adolescents. Am J Med Genet B Neuropsychiatr Genet 141(5):473-476

Livak K (1997) ABI Prism 7700 Sequence detection system

Lohmann DR, Gallie BL (2004) Retinoblastoma: revisiting the model prototype of inherited cancer. Am J Med Genet C Semin Med Genet 129(1):23-28

Motegi T, Ikeda K, Watanabe K, Yanagawa Y, Minoda K (1987) Deletion (13)(q13q14.3) with retinoblastoma: confirmation and extension of a recognisable pattern of clinical features in retinoblastoma patients with $13 q$ deletion. J Med Genet 24(11):696-697

Motegi T, Kaga M, Yanagawa Y, Kadowaki H, Watanabe K, Inoue A, Komatsu M, Minoda K (1983) A recognizable pattern of the midface of retinoblastoma patients with interstitial deletion of 13q. Hum Genet 64(2):160-162

Pescucci C, Caselli R, Grosso S, Mencarelli MA, Mari F, Farnetani MA, Piccini B, Artuso R, Bruttini M, Priolo M, Zuffardi O, Gimelli S, Balestri P, Renieri A (2006) 2q24-q31 Deletion: report of a case and review of the literature. Eur J Med Genet

Sampieri K, Hadjistilianou T, Mari F, Speciale C, Mencarelli MA, Cetta F, Manoukian S, Peissel B, Giachino D, Pasini B, Acquaviva A, Caporossi A, Frezzotti R, Renieri A, Bruttini M (2006) Mutational screening of the RB1 gene in Italian patients with retinoblastoma reveals 11 novel mutations. J Hum Genet 51(3):209-216

Scheffer H, Van Der Vlies P, Burton M, Verlind E, Moll AC, Imhof SM, Buys CH (2000) Two novel germline mutations of the retinoblastoma gene (RB1) that show incomplete penetrance, one splice site and one missense. J Med Genet 37(7):E6

Sharp AJ, Locke DP, McGrath SD, Cheng Z, Bailey JA, Vallente RU, Pertz LM, Clark RA, Schwartz S, Segraves R, Oseroff VV, Albertson DG, Pinkel D, Eichler EE (2005) Segmental duplications and copy-number variation in the human genome. Am J Hum Genet 77(1):78-88

Skrypnyk C, Bartsch O (2004) Retinoblastoma, pinealoma, and mild overgrowth in a boy with a deletion of RB1 and neighbor genes on chromosome 13q14. Am J Med Genet A 124(4):397-401

Yamagata K, Andreasson KI, Sugiura H, Maru E, Dominique M, Irie Y, Miki N, Hayashi Y, Yoshioka M, Kaneko K, Kato H, Worley PF (1999) Arcadlin is a neural activity-regulated cadherin involved in long term potentiation. J Biol Chem 274(27): 194731979 